\title{
Belanja Pemerintah dan Peningkatan Sumber Daya Manusia di Indonesia
}

\author{
Adhitya Wardhana ${ }^{1}$, Bayu Kharisma ${ }^{2}$, Dita Selyna Sulandari ${ }^{3}$ \\ ${ }^{1}$ Departemen Ilmu Ekonomi, Universitas Padjadjaran, adhitya.wardhana@fe.unpad.ac.id \\ ${ }^{2}$ Departemen Ilmu Ekonomi,, Universitas Padjadjaran, bayu.kharisma@unpad.ac.id \\ ${ }^{3}$ Departemen Ilmu Ekonomi,, Universitas Padjadjaran, ditaselynas.ds@gmail.com
}

\begin{abstract}
This study aims to analyze the effect of government spending on increasing the human development index (HDI) in Indonesia. The research method used in this study is the Fixed Effect Model and the Random Effect Model with 33 provinces in Indonesia. The results showed that government spending on the functions of the economy, health, education, and infrastructure had a statistical and significant effect on the human development index. In addition, the results of each component of the human development index (life expectancy, average length of schooling, and income per capita) have a significant effect. Expenditures on education, health, economy and infrastructure need to be considered by the government by increasing capital expenditures for the purposes of human resource capacity. In addition, investment in human capital in the form of research and development is devoted to the dropout community. Meanwhile, anti-corruption enforcement in the public sector must be increased so that the budget used for human resource development can run effectively and efficiently, especially human capital development. The contribution of this research is that it has never been carried out in an inter-provincial scope in Indonesia.
\end{abstract}

Keywords: government expenditure, HDI, panel data

\begin{abstract}
ABSTRAK
Penelitian ini bertujuan untuk menganalisis pengaruh belanja pemerintah terhadap peningkatan indeks pembangunan manusia (IPM) di Indonesia. Adapun metode penelitian yang digunakan dalam penelitian ini adalah Fixed Effect Model dan Random Effect Model dengan 33 Provinsi di Indonesia. Hasil penelitian menunjukkan bahwa pengeluaran pemerintah pada fungsi ekonomi, kesehatan, pendidikan, dan infrastruktur berpengaruh secara statistik dan signifikan terhadap indeks pembangunan manusia. Selain itu, hasil setiap komponen indeks pembangunan manusia (angka harapan hidup, rata-rata lama sekolah, dan pendapatan per kapita) berpengaruh secara signifikan. Pengeluaran pendidikan, kesehatan, ekonomi dan infrastruktur perlu diperhatikan pemerintah dengan cara meningkatkan belanja modal untuk keperluan kapasitas SDM. Selain itu, investasi pada modal manusia dalam bentuk penelitian dan pengembangan dikhususkan untuk masyarakat putus sekolah. Sementara itu, adanya penegakan anti korupsi di sektor publik harus ditingkatkan agar anggaran yang digunakan untuk peningkatan SDM dapat berjalan efektif dan efisien terutama pengembangan modal manusia. Kontribusi penelitian ini adalah belum pernah dilakukan dalam ruang lingkup antar provinsi di Indonesia.
\end{abstract}

Kata Kunci : pengeluaran pemerintah, IPM, panel data

Naskah diterima: 23-06-2021, direvisi: 09-06-2021, diterbitkan: 01-09-2021

ISSN: 2355-0295, e-ISSN: 2549-8932 


\section{PENDAHULUAN}

Pembangunan manusia menjadi salah satu syarat penting dalam meningkatkan output perekonomian dalam suatu negara. Peningkatan output pembangunan antara lain dapat bersumber dari kontribusi input seperti modal dan tenaga kerja. Tenaga kerja yang memiliki keahlian merupakan keberhasilan pemerintah dalam meningkatkan kualitas SDM. Dalam beberapa kasus, beberapa negara dapat berhasil dalam pertumbuhan ekonomi, namun banyak yang mengalami kegagalan pada pembangunan manusia. Sementara itu, adanya kegagalan pembangunan manusia dapat terlihat dari perkembangan sektor kesehatan, pendidikan dan kesamaan gender. Pembangunan ekonomi negara ditentukan dari penggunaan sumber daya manusia yang efektif (Supadi, 2011).

Keberhasilan pembangunan manusia dapat diukur dengan indeks pembangunan manusia (IPM). Arubayi \& Ikoya (2009) menunjukkan bahwa pembangunan manusia dapat berdampak terhadap kemajuan negara. Selain itu, indikator IPM dianggap merupakan indikator untuk menghitung kemajuan sumber daya manusia, dimana negara yang memiliki nilai IPM tinggi maka negara tersebut cenderung memiliki kualitas SDM yang baik. Indonesia menjadi salah satu negara yang tertinggi dalam jumlah penduduk sehingga pemerintah memiliki beban berat dalam meningkatkan kualitas SDM. Perhitungan IPM digunakan juga untuk melihat kinerja pemerintah dan pencapaiaan target pembangunan nasional.

Menurut BPS (2019), nilai IPM Indonesia mengalami peningkatan pada tahun 2020 dengan nilai 70.94 dan kenaikan nilai IPM tahun 2020 sebesar 0.02 dari tahun sebelumnya. Nilai IPM dalam rentang 70-80 merupakan kategori tinggi dalam pembangunan manusia. Peningkatan IPM di Indonesia merupakan bentuk kontribusi pemerintah daerah dalam meningkatkan pembangunan manusia. Perkembangan nilai IPM setiap provinsi di Indonesia dapat dilihat pada Gambar 1. Secara umum provinsi Indonesia sudah menempati nilai IPM berkategori tinggi, hanya ada beberapa provinsi yang belum mendekati IPM di Indonesia. Provinsi di Indonesia yang belum mendekati nilai IPM Indonesia yaitu NTT, NTB Kalimantan Barat, Sulawesi Tengah, Sulawesi Barat, Maluku, Maluku Utara, Papua Barat dan Papua.

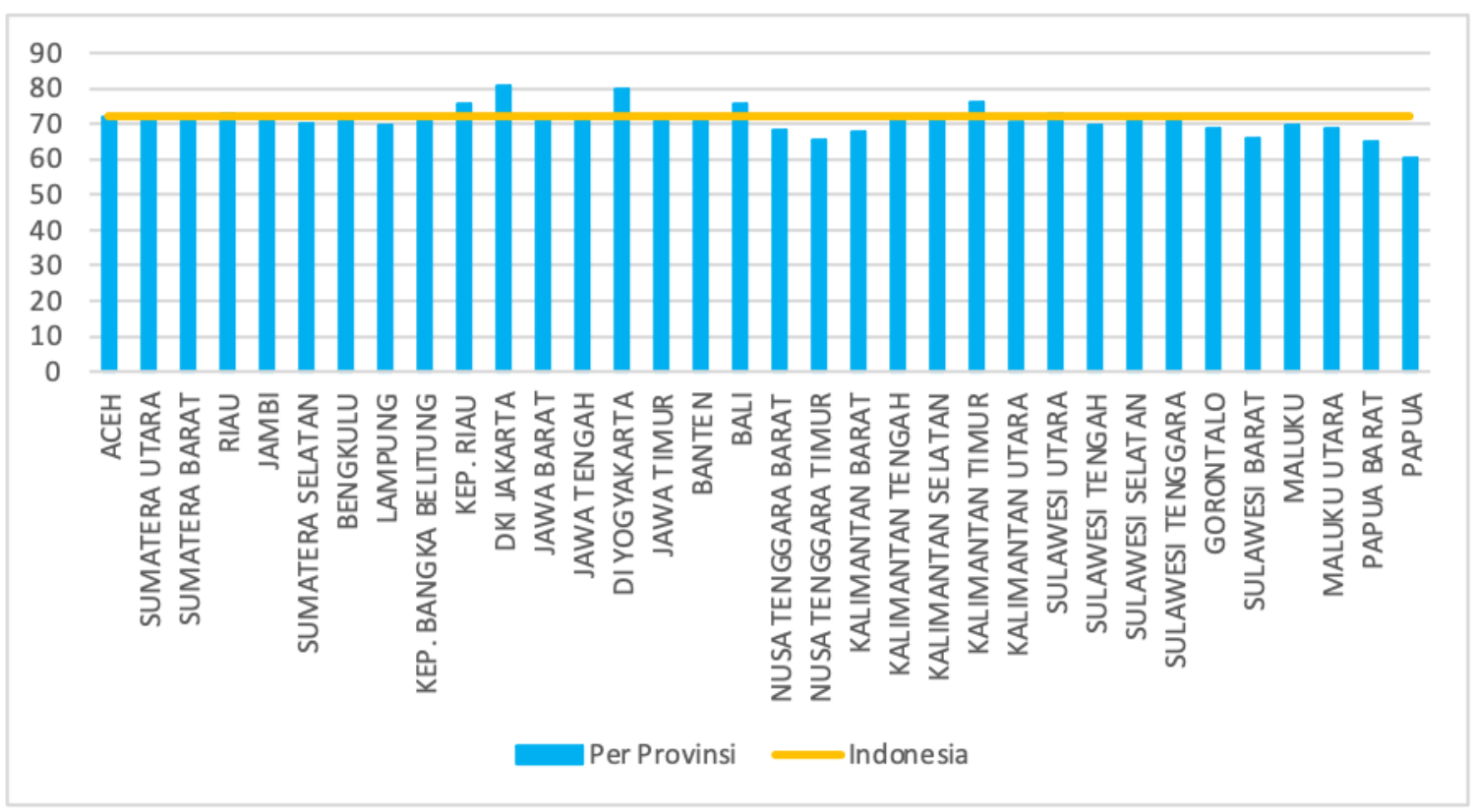

Sumber : BPS (diolah)

Gambar 1. Nilai Indeks Pembangunan Manusia (IPM) Provinsi di Indonesia Tahun 2020 
Secara umum, meskipun nilai IPM provinsi di Indonesia terus mengalami perbaikan, namun beberapa indikator pendidikan lainnya masih belum mencapai target yang dicanangkan oleh pemerintah. Salah satu tolak ukur keberhasilan pendidikan dapat dilihat dari rata-rata lama sekolah (RLS), dimana nilai tersebut menjadi ukuran untuk perkembangan masyarakat dalam menamatkan pendidikan dan program pemerintah wajib belajar sembilan tahun untuk melihat tingkat pendidikan yang ditamatkan oleh masyarakat. Pencapaian pendidikan yang dilihat dari tamatan pendidikan masyarakat berdasarkan jenjang pendidikan dijadikan sebagai ukuran keberhasilan pemerintah dalam meningkatkan kualitas SDM.

Masih banyak provinsi yang belum mencapai program wajib belajar sembilan tahun. Hasil ini tercermin pada program pemerintah semua provinsi belum dapat memenuhi pencapaian pendidikan, dimana provinsi yang belum mencapai program wajib belajar sembilan tahun 2019-2020 sebanyak 18 provinsi (BPS, 2020). Dengan demikian, beberapa provinsi tersebut yang belum mencapai wajib belajar sembilan menjadi beban pemerintah daerah dalam meningkat pembangunan kualitas SDM. Meskipun, secara umum IPM secara umum sudah membaik tetapi perkembangan RLS beberapa provinsi di Indonesia yang belum mencapai wajib belajar sembilan tahun.

Indikator kesehatan merupakan salah satu indikator pembentuk indeks pembangunan manusia (IPM) selain faktor pendidikan. Peningkatan kesehatan menjadi kunci keberhasilan pada kualitas hidup masyarakat dalam pembangunan suatu negara. Kualitas hidup sebagai tolak ukur keberhasilan program yang dibuat oleh pemerintah yang dapat meningkatkan derajat kesehatan hidup masyarakat. Keberhasilan kualitas hidup suatu negara dapat dilihat dari perkembangan angka harapan hidup (AHH). Angka harapan hidup sering digunakan sebagai penilaian derajat kesehatan maupun kualitas hidup penduduk dalam suatu negara. Menurut Todaro dan Smith (2012), angka harapan hidup adalah salah satu indikator kesehatan untuk melihat keberhasilan pembangunan manusia. Angka harapan hidup digunakan untuk mengevaluasi pertumbuhan kesehatan suatu negara dan pembangunan ekonomi (Mahumud, Hossain, Hossain, Islam, \& Rawal, 2013).

Kondisi angka harapan hidup berdasarkan provinsi di Indonesia mengalami peningkatan di tahun 2019 dibandingkan tahun sebelumnya. Perkembangan AHH menjadi ukuran keberhasilan pemerintah dalam menanggulangi penyakit dan peningkatan kesehatan masyarakat. Pencapaian angka harapan hidup Indonesia menjadi tolak ukur Pemerintah Daerah untuk meningkatkan kualitas hidup penduduk. Keberhasilan pencapaian kualitas hidup setiap daerah dapat dilihat dari pencapaian $\mathrm{AHH}$ yang sudah menyamai atau melebihi Indonesia. Sementara itu, provinsi yang telah melewati AHH Indonesia yaitu DI Yogyakarta, Jawa Tengah, Kalimantan Timur, Jawa Barat, DKI, Kalimantan Utara, Bali, Sumatera Utara dan Riau. Kemudian daerah yang mendekati nilai AHH Indonesia yaitu Jawa Timur dan Bali, sedangkan daerah lainnya masih dibawah nilai AHH sebesar 70 tahun (BPS, 2020).

Peningkatan kualitas SDM tidak lepas dari peran pemerintah dalam mengeluarkan anggaran belanja untuk kesehatan dan pendidikan. Pemerintah berperan dalam mendorong standar hidup melalui alokasi belanja kesehatan. Pemerintah pusat maupun daerah memiliki wewenang untuk mengelola keuangannya. Kebijakan pemerintah dalam meningkatkan standar hidup melalui peran belanja pemerintah bidang kesehatan. Pengeluaran pemerintah untuk kesehatan bertujuan meningkatkan standar hidup dan kualitas SDM. Besaran pengeluaran kesehatan untuk menopang kesehatan seiring dengan pertambahan penduduk. Pertambahan penduduk di setiap daerah menjadi beban pemerintah dalam menyediakan sarana kesehatan. Oleh karena itu, diperlukan anggaran kesehatan yang dapat memenuhi standar pelayanan kesehatan.

Pengeluaran pemerintah bidang kesehatan antar provinsi Indonesia masih beragam (BPS, 2020). Ada beberapa daerah yang sudah mengacu UU No 36 tahun 2019 bahkan melebihi anggaran 10\% dari APBD. 
Keberagaman anggaran kesehatan setiap provinsi mencerminkan pembangunan infrastruktur sektor kesehatan, sedangkan kondisi pengeluaran kesehatan masih banyak daerah yang belum memenuhi standar pelayanan minimum. Selanjutnya pengeluaran pendidikan menjadi salah satu anggaran yang digunakan untuk meningkatkan kualitas SDM selain anggaran kesehatan. Pada dasarnya bahwa anggaran pendidikan dilakukan untuk mendanai pelaksanaan pendidikan yang menjadi urusan pemerintah provinsi, kabupaten maupun kota. Berdasarkan Undang-Undang Republik Indonesia Nomor 20 Tahun menyebutkan dana pendidikan dialokasikan minimal 20\% dari APBD.

Mekanisme anggaran pendidikan kepada daerah merupakan pelaksanaan kebijakan desentralisasi. Kondisi anggaran pendidikan provinsi di Indonesia cenderung sudah memenuhi UU No 20 Tahun 2003. Persentase anggaran pendidikan yang cukup besar dilakukan untuk memenuhi penyediaan sarana pendidikan seiring pertambahan penduduk yang terus meningkat. Pertambahan penduduk membuat pemerintah daerah untuk terus menyediakan sarana pendidikan dalam memenuhi program pendidikan seperti program wajib belajar sembilan dan dua belas tahun.

Setiap komponen indeks pembangunan manusia berkaitan erat dengan pengeluaran di berbagai sektor. Pengeluaran publik memainkan peran penting dalam memastikan pembangunan manusia yang berkelanjutan. Meskipun perubahan besar telah terjadi di provinsi Indonesia pada pengeluaran sektoral yang berbeda untuk pembangunan manusia. Kondisi pendidikan di Indonesia yang belum merata membuat pemerintah daerah bekerja keras untuk meningkatkan pendidikan masyarakat. Begitu juga dengan aspek kesehatan dan pertambahan penduduk akan bergantung terhadap pengeluaran pemerintah.

Penelitian sebelumnya (Hao \& Fan, 2001; Sen, 2000) berpendapat bahwa peningkatan pertumbuhan dengan memperbesar ketersediaan dan memperluas distribusi kebutuhan dasar diharapkan dapat meningkatkan kesejahteraan. Upaya peningkatan kesejahteraan melalui peningkatan kualitas hidup yang terwujud dalam pencapaian pendidikan yang lebih tinggi, hidup lebih sehat, berkelanjutan lingkungan dan harapan hidup yang lebih besar. Pengeluaran publik semakin penting ketika mendorong peningkatan kualitas hidup, penurunan ketimpangan dan pengangguran dan pengentasan kemiskinan.

Hao \& Fan (2001) serta Sen (2000) menjelaskan bahwa pengeluaran pemerintah untuk lebih sinergis dalam mewujudkan pencapaian pendidikan dan kesehatan yang lebih tinggi melalui pengeluaran pemerintah menurut fungsi ekonomi, pendidikan, kesehatan, perumahan dan fasilitas umum. Dalam mendorong peningkatan kualitas SDM di Indonesia, beberapa indikator pendidikan dan kesehatan sebagai salah satu contoh yang harus segera dibenahi oleh pemerintah pusat maupun daerah Berdasarkan kondisi pendidikan dan kesehatan yang sudah diuraikan diatas masih terjadi kelemahan dan ketidakmerataan di setiap daerah dalam meningkatkan kualitas SDM. Secara spefisik masih banyak sektor pendidikan dan kesehatan yang perlu dibenahi di setiap daerah, hal ini tidak terlepas dari kontribusi anggaran pemerintah dalam menyediakan infrastruktur pendidikan dan kesehatan. Ketergantungan anggaran publik semakin besar dalam pencapaian kualitas SDM yang baik.

Widodo, Irawan, Oktavianti, \& Anisa, (2020) menguji pengaruh tiga faktor yaitu pengeluaran pemerintah untuk pendidikan, kesehatan, dan upah minimum terhadap indeks pembangunan manusia di lima provinsi terpilih di Indonesia. Hasil penelitiannya menunjukkan bahwa pengeluaran pemerintah untuk pendidikan dan kesehatan membawa pengaruh yang positif tetapi tidak signifikan terhadap indeks pembangunan manusia; Padahal, upah minimum ternyata positif dan berpengaruh signifikan terhadap indeks pembangunan manusia. Secara keseluruhan rata-rata IPM tidak jauh berbeda dan tidak ada perbedaan antar provinsi di Sumatera Selatan dari kisaran 68 persen hingga 70 persen. Namun dari lima provinsi di Sumatera Selatan, terdapat dua provinsi dengan angka IPM yang lebih tinggi dibandingkan dengan provinsi lainnya, yaitu Provinsi Jambi dan Provinsi Bangka Belitung. 
Sartiyah, Hartoyo, Syaukat, \& Oktaviani, (2017) menunjukkan bahwa pengeluaran pemerintah untuk pendidikan, pendapatan per kapita di daerah utama berpengaruh positif dan signifikan terhadap pendidikan, sedangkan kemiskinan berpengaruh negatif terhadap pendidikan di Provinsi Aceh. Namun, pendidikan memiliki respon yang kecil terhadap pengeluaran pemerintah untuk pendidikan di Provinsi Aceh. Berdasarkan hasil penelitian, disarankan kepada pemerintah daerah untuk meningkatkan pelayanan dan pengawasan pendidikan di daerah yang baru berdiri, khususnya di daerah terpencil.

Dalam penelitian ini akan mengkaji seberapa besar pengaruh dari masing-masing pengeluaran Publik terhadap kualitas SDM yang dilihat dari Indeks Pembangunan Manusia (IPM). Indikator pembentuk IPM seperti pendidikan, kesehatan dan pendapatan perkapita di setiap provinsi masih belum merata, hal ini terlihat dari RLS yang belum mencapai program wajib belajar, Angka Harapan Hidup (AHH) di beberapa daerah yang belum mendekati AHH Nasional dan perbedaan kesejahteraan disetiap yang belum merata.

Dalam menganggarkan pengeluaran publik perlu adanya perencanaan anggaran yang berbasis kinerja dan berjalan efektif. Perencanaan anggaran dilakukan untuk mencapai peningkatan kualitas SDM di tahun berikutnya. Dengan demikian, penelitian ini akan melihat pengaruh pengeluaran pemerintah (ekonomi, pendidikan, kesehatan dan infrastruktur) tahun sebelumnya terhadap perkembangan IPM. Selama ini anggaran publik belum berjalan efektif dikarenakan beberapa pemerintah daerah belum dapat memenuhi peraturan pemerintah dalam persentase belanja. Oleh karena itu, penelitian ini akan mengkaji secara parsial untuk melihat pengaruh kombinasi dari belanja pemerintah terhadap sektor pendidikan (RLS), sektor kesehatan (AHH) dan pendapatan perkapita. Adapun kontribusi penelitian mengenai pengaruh belanja pemerintah terhadap peningkatan indikator pembentuk IPM belum pernah dilakukan dalam ruang lingkup antar provinsi di Indonesia.

\section{KAJIAN LITERATUR}

Fransisco et al. (2019) menganalisis bagaimana alokasi belanja pemerintah dalam meningkatkan Indeks Pembangunan Manusia di Kabupaten dan Kota di Provinsi Jambi menggunakan model regresi GMM (Generalized Method of Moments). Hasil analisis menyatakan bahwa alokasi belanja sektor ekonomi, dan alokasi belanja sektor perumahan dan penyediaan sarana prasarana umum, dan alokasi belanja sektor pendidikan berpengaruh signifikan terhadap IPM.

Edeme dan Nkalu (2019) menganalisis pengeluaran publik untuk pendidikan, kesehatan, pertanian dan pembangunan desa, sumberdaya air, energi serta perumahan dan perlindungan lingkungan terhadap pembangunan manusia di 20 negara bagian di Nigeria. Analisis empiris menunjukkan bahwa pengeluaran publik untuk pendidikan, kesehatan, pertanian dan pembangunan desa, sumberdaya air, energy, serta perumahan dan perlindungan lingkungan dapat meningkatkan pembangunan manusia. Namun pengaruh pengeluaran publik untuk pendidikan, kesehatan, pertanian dan pembangunan desa, dan sumberdaya air lebih besar daripada pengaruh pengeluaran publik untuk energi serta perumahan dan perlindungan lingkungan terhadap pembangunan manusia.

Fadilah et al. (2018) menganalisis pengaruh pengeluaran pemerintah terhadap indeks pendidikan, indeks kesehatan, dan indeks pendapatan daerah di 38 Kabupaten dan Kota di Jawa Timur dengan menggunakan Fixed Effect Model dan Random Effect Model. Hasil analisis menunjukkan bahwa pengeluaran pemerintah terhadap pendidikan, kesehatan, dan ekonomi dapat meningkatkan setiap komponen dalam indeks pembangunan manusia. Selain itu, pengeluaran pemerintah terhadap infrastruktur secara signifikan mempengaruhi indeks pendidikan dan pendapatan, tapi tidak signifikan mempengaruhi indeks kesehatan.

Kusharjanto dan Kim (2011) menganalisis hubungan antara infrastruktur dan indeks pembangunan manusia di Pulau Jawa, tidak termasuk daerah kota besar, seperti Jakarta, Semarang, Bandung, dan Surabaya. Hasil penelitian menunjukkan bahwa secara signifikan, peningkatan infrastruktur juga dapat meningkatkan 
pembangunan manusia. Secara khusus, infrastruktur untuk listrik memiliki pengaruh yang lebih besar terhadap peningkatan pengembangan manusia dibandingkan dengan infrastruktur lain, seperti air bersih, jalan, ataupun jumlah kelas. Untuk setiap kenaikan $1 \%$ proporsi rumah tangga yang dapat mengakses listrik, IPM meningkat sebesar $0.2 \%$. Sedangkan peningkatan proporsi rumah tanggai dengan penggunaan pada infrastruktur lain setiap 1\%-nya hanya meningkatkan sekitar $0.01 \%$ sampai $0.03 \%$ IPM.

Mohanty et al. (2016) menyebutkan bahwa infrasturuktur memiliki peranan penting dalam meningkatkan dan menstabilkan IPM. Dengan menggunakan model panel data untuk menganalisis pengaruh infrastruktur terhadap komponen IPM di Odisha, India, Mohanty et al. (2016) menjelaskan bahwa telekomunikasi, listrik, bank, sekolah, dan fasilitas air bersih memiliki peran

\section{METODE PENELITIAN}

Penelitian ini menggunakan pendekatan kuantitatif untuk menganalisis pengaruh belanja pemerintah terhadap peningkatan sumber daya manusia di Indonesia. Data yang digunakan dalam penelitian ini merupakan data sekunder Direktorat Jenderal Perimbangan Keuangan untuk variable anggaran fungsi kesehatan, anggaran fungsi ekonomi, anggaran fungsi pendidikan, anggaran kesehatan dan anggaran untuk infrastrukur. Sedangkan data yang diperoleh dari Badan Pusat Statistik, yaitu data untuk variabel indeks pembangunan manusia, rata lama sekolah (RLS), angka harapan hidup (AHH) dan pendapatan per kapita untuk 33 Provinsi di Indonesia. Model yang digunakan dalam penelitian ini merupakan Panel Data dengan menggabungkan data time-series dari tahun 2010 - 2020 dan data cross-section dari 33 Provinsi di Indonesia.

Selanjutnya, untuk menentukan model yang digunakan dalam penelitian ini, Penulis mengikuti model yang digunakan oleh Edeme dan Nkalu (2019), yaitu model penelitian yang menganalisis bagaimana pengaruh pengeluaran pemerintah terhadap indeks pembangunan manusia. Pentingnya setiap indikator indeks pembangunan manusia (IPM) untuk melihat kemajuan atau perkembangan sumber daya manusia, Penulis menganalisis seluruh komponen dalam indeks pembangunan manusia, termasuk model distributional impact untuk melihat pengaruh perubahan antara indeks pembangunan manusia dan perubahan pada pengeluaran pemerintah. $\mathrm{HDI}_{\mathrm{it}}=\beta_{0}+\beta_{1} \mathrm{LnECO}_{\mathrm{it}}+\beta_{2} \mathrm{LnEduc}_{\mathrm{it}}+\beta_{3} \mathrm{LnFasum}$
${ }_{\mathrm{it}}+\beta_{4} \mathrm{LnHe}_{\mathrm{it}}+\mathrm{u}_{\mathrm{it}}$

dimana $\mathrm{HDI}_{\mathrm{it}}$ merupakan indeks pembangunan manusia. LnECO $_{\text {it }}$ adalah pengeluaran pemerintah fungsi ekonomi dalam bentuk logaritma natural. LnFasum $_{\text {it }}$ adalah pengeluaran pemerintah bidang infrastruktur (perumahan dan fasilitas umum) dalam bentuk logaritma natural. LnEduc adalah pengeluaran pemerintah fungsi pendidikan dalam bentuk logaritma natural. $\mathrm{LnHe}_{\text {it }}$ adalah pengeluaran pemerintah fungsi kesehatan dalam bentuk logaritma natural. i merupakan data cross section yang terdiri dari 33 provinsi di Indonesia, dan t merupakan data periode penelitian, yaitu tahun 2010 sampai 2020.

Selanjutnya, penelitian ini akan melihat pengaruh pengeluaran pemerintah (ekonomi, pendidikan, kesehatan dan infrastruktur) terhadap komponen indeks pembangunan manusia dapat dianalisis melalui model di bawah ini:

$$
\begin{gathered}
A H H_{i t}=\beta_{0}+\beta_{1} C P E X_{i t}+\varepsilon_{i t} \\
R L S_{i t}=\beta_{0}+\beta_{1} C P E X_{i t}+\varepsilon_{i t} \\
\text { LnInc }_{i t}=\beta_{0}+\beta_{1} C P E X_{i t}+\varepsilon_{i t}
\end{gathered}
$$

dimana $\mathrm{AHH}_{\mathrm{it}}$ merupakan angka harapan hidup, RLS $_{\text {it }}$ merupakan rata-rata lama sekolah, LnIncm it $_{\text {t }}$ merupakan pendapatan per kapita dalam bentuk logaritma natural, dan $\mathrm{CPEX}_{\text {it }}$ merupakan kombinasi atau jumlah pengeluaran pemerintah untuk sumber daya manusia atau pembangunan manusia.

\section{PEMBAHASAN}

Hasil penelitian akan dijelaskan berdasarkan model penelitian yang sudah dijelaskan dalam metode penelitian. Hasil uji hausman dan uji chow menjelaskan model yang terbaik dari seluruh model penelitian menggunakan fixed effect model. Model penelitian yang digunakan yaitu model 
Generalized Least Square (GLS). Model Generalized Least Square (GLS) untuk melakukan koreksi uji asumsi klasik seperti autokorelasi dan heterokedastisitas (Gujarati, 2006). Hasil estimasi pada model pertama dan kedua dapat dilihat pada Tabel 1 dan Tabel 2.

Tabel 1.

Hasil Estimasi Pengaruh Belanja Pemerintah Terhadap IPM di Indonesia (Fixed Effects)

\begin{tabular}{ll}
\hline Variabel & \multicolumn{1}{c}{ HDI } \\
\hline C & $-5.698907^{*}$ \\
LNECO & $(3.200285)$ \\
& $0.836416^{* * *}$ \\
LNEDUC & $(0.162538)$ \\
& $0.893821^{* * *}$ \\
LNFASUM & $(0.051370)$ \\
& $0.369627^{* * *}$ \\
LNHE & $(0.088999)$ \\
& $0.659946^{* * *}$ \\
\hline R. square (adj) & $(0.108182)$ \\
F-statistic & 0.969313 \\
Prob(F-statistic) & 317.7439 \\
\hline Sumber Hasil perhitugan
\end{tabular}

Sumber : Hasil perhitungan

Signifikan pada tingkat $1 \%(* * *), 5 \%(* *), 10 \%(*)$.

Hasil Tabel 1 pada persamaan pertama menunjukkan bahwa pengeluran pemerintah yang merupakan fungsi pendidikan menjadi variabel bebas (independen) yang paling memengaruhi IPM. Hasil ini sejalan dengan penelitian sebelumnya (Edeme dan Nkalu (2019) yang menyatakan bahwa pendidikan meningkatkan kemampuan orang untuk berkontribusi lebih banyak pada proses pembangunan dan meningkatkan tingkat produktivitas. Pendidikan menjamin masyarakat untuk hidup lebih lama dan lebih sehat, berpengetahuan luas dan meningkatkan kualitas lingkungan. Jung dan Thorbecke (2003) menunjukkan bahwa pengeluaran pendidikan berdampak positif pada pembangunan manusia. Penyediaan infrastruktur di sektor pendidikan akan membantu peningkatan kualitas pengetahuan masyarakat. Sementara itu, Astri et al., (2013); Sanggelorang et al., (2015) dan Wijayanto et al., (2015) menunjukkan bahwa anggaran yang lebih tinggi untuk sektor pendidikan memiliki pengaruh yang signifikan terhadap IPM. Perencanaan anggaran pemerintah bidang pendidikan yang sesuai akan meningkatkan kualitas SDM.

Adanya peraturan pemerintah, UndangUndang Republik Indonesia Nomor 20 Tahun 2003 Tentang Sistem Pendidikan Nasional untuk menyediakan anggaran pendidikan minimal 20\% dari APBD memperlihatkan pemerintah pusat maupun daerah fokus dalam meningkatkan pendidikan di Indonesia. Pendidikan yang tidak merata terlihat dari daerah yang tertinggal sehingga rata-rata lama sekolah cenderung lebih rendah. Taraf pendidikan masyarakat yang rendah berawal dari sebagian masyarakat belum mendapatkan layanan pendidikan yang layak. Distribusi guru yang belum merata, jumlah sekolah yang terbatas dan jarak sekolah yang jauh di perumahan menjadi hambatan dalam meningkatkan pendidikan masyarakat di Indonesia. Selain itu permasalahan pendidikan di Indonesia menjadi lebih kompleks akibat distribusi penduduk, karakteristik masyarakat dari sisi budaya dan geografis yang tidak merata. Menurut Saraswati, (2013) dalam Fadilah et al., (2018) menyatakan bahwa kompleksitas pendidikan di Indonesia 
disebabkan oleh adanya distribusi penduduk, struktur sosial budaya, dan karakteristik masyarakat yang tidak merata, baik dari segi budaya maupun geografis. Hambatan pendidikan tersebut dapat dikurangi dengan perencanaan anggaran pendidikan yang sesuai dengan permasalahan pendidikan di Indonesia. Oleh karena itu, pengeluaran pendidikan memiliki peranan penting dalam memengaruhi IPM di Indonesia. Besaran alokasi dana pendidikan menjadi penentu keberhasilan pemerintah dalam meningkatkan kualitas SDM.

Selanjutnya, variabel belanja fungsi ekonomi memiliki nilai koefisien terbesar dalam memengaruhi IPM, disamping pengeluaran pendidikan. Belanja fungsi ekonomi memengaruhi signifikan dengan arah positif terhadap IPM. Belanja fungsi ekonomi adalah belanja untuk kegiatan administrasi dan operasional pada tenaga kerja, perdagangan, pengembangan usaha dan KUKM dan sektor ekonomi (Menteri Keuangan Republik Indonesia, 2015).

Pengeluaran pemerintah di bidang ekonomi menjadi pendorong peningkatan kegiatan sektor riil sehingga secara tidak langsung akan memacu peningkatan pendapatan masyarakat. Pendapatan yang lebih tinggi dapat mendorong perkembangan manusia melalui kesehatan yang lebih baik dan pencapaian pendidikan yang lebih tinggi, yang pada akhirnya meningkatkan potensi penghasilan individu (Sahn dan Younger, 1999). Pengeluaran pemerintah fungsi ekonomi diharapkan dapat menyediakan lapangan kerja maupun fasilitas umum yang memberikan efek pengganda bagi kesejahteraan penduduk. Jadi belanja pemerintah sektor ekonomi dapat mendorong produktivitas masyarakat dalam bekerja dikarenakan perusahaan menginginkan tenaga kerja yang memiliki keahlian yang sesuai dengan kebutuhan perusahaan. Fadilah et al., (2018) mengungkapkan bahwa pengeluaran ekonomi mempunyai kontribusi yang efektif dalam meningkatkan pertumbuhan ekonomi nasional. Dana yang dialokasikan pemerintah untuk bidang ekonomi mampu meningkatkan produktivitas dan kegiatan perekonomian masyarakat yang pada akhirnya meningkatkan daya beli masyarakat. Peningkatan daya beli masyarakat dapat meningkatkan permintaan output di sektor pendidikan dan kesehatan.

Selanjutnya, variabel belanja kesehatan berpengaruh positif dan signifikan terhadap IPM di Indonesia. Pengeluaran kesehatan memainkan peranan besar dalam status kesehatan untuk menciptakan lingkungan hidup sehat. Edeme dan Nkalu (2019) menyatakan bahwa pengeluaran publik untuk kesehatan dapat meningkatkan kesejahteraan yang diakibatkan oleh pengurangan beban penyakit. Ocampo (1998) menunjukkan bahwa pengeluaran kesehatan berhubungan positif dengan pembangunan manusia. Kesehatan menjadi kebutuhan dasar dalam pembangunan nasional yang dimulai dengan melalukan investasi melalui pelayanan kesehatan sehingga dapat meningkatkan kualitas SDM. Alokasi dana kesehatan memberikan peran utama dalam peningkatan kesehatan yang menjadikan kualitas SDM semakin baik. Kontribusi dana kesehatan dapat ditunjukkan dari angka harapan hidup dan nilai IPM yang semakin meningkat. Studi Razmi et al., (2012) mengungkapkan bahwa alokasi dana untuk peningkatan kesehatan berpengaruh positif terhadap IPM.

Pengeluaran pemerintah bidang infrastruktur memengaruhi signifikan terhadap IPM Indonesia. infrastruktur berperan dalam menjalankan kegiatan sosial, ekonomi dan budaya. Edeme dan Nkalu (2019), menjelaskan pengeluaran infrastruktur memengaruhi searah dengan indeks pembangunan manusia. Pengeluaran infrastruktur digunakan untuk menyediakan sarana dan prasarana untuk melancarkan aktifitas di bidang kesehatan dan pendidikan masyarakat. Fasilitas jalan raya, listrik air minum dapat terealisasi dengan perencanaan anggaran infrastruktur yang baik. Pengeluaran infrastruktur menjadi factor pendorong dalam meningkatkan pendidikan dan kesehatan sehingga pembangunan manusia yang diharapkan dapat tercapai. Studi lain yang menyatakan bahwa pengeluaran pemerintah untuk infrastruktur berpengaruh signifikan terhadap IPM dilakukan oleh R. Edeme (2014) yang menemukan bahwa variabel infrastruktur termasuk perumahan, energi, sanitasi dan program pembangunan pedesaan berpengaruh signifikan terhadap indeks 
pembangunan manusia di Nigeria. Temuan tersebut menunjukkan bahwa pengeluaran pemerintah pada sektor infrastruktur memengaruhi indeks pembangunan manusia melalui dimensi pendidikan dan ekonomi.

Pada model kedua, penelitian ini akan melihat perkembangan (perubahan) IPM sebagai variable tidak bebas yang dipengaruhi oleh variabel bebas pada tahun sebelumnya. Perkembangan positif IPM dipengaruhi oleh upaya belanja pemerintah (ekonomi, pendidikan, Kesehatan, infrastuktur) pada tahun sebelumnya. Model kedua penelitian ini, akan melihat perencanaan pengeluaran pemerintah tahun sebelumnya yang dapat berdampak terhadap peningkatan IPM. Perencanaan anggaran belanja pemerintah yang baik akan meningkatkan pembangunan manusia. Pembangunan manusia yang diproksikan dengan IPM dipengaruhi secara signifikan oleh belanja pemerintah bidang ekonomi, kesehatan, pendidikan dan infrastruktur tahun sebelumnya. Pemerintah dalam merumuskan perencanaan anggaran berdasarkan kinerja akan mempertimbangkan kondisi tahun sebelumnya sehingga pembangunan manusia yang diharapkan dapat tercapai. Anggaran belanja pemerintah untuk kepentingan pembangunan manusia akan menyesuaikan dengan kondisi yang terjadi setiap tahunnya.

Pada Tabel 2 menjelaskan pengaruh pengeluaran pemerintah secara spesifik memengaruhi variabel pembentuk IPM (pendidikan, kesehatan dan pendapatan perkapita). Variabel pendidikan untuk melihat capaian pendidikan masyarakat melalui rata lama sekolah (RLS), sedangkan variabel kesehatan menggunakan angka harapan hidup (AHH) dan pendapatan perkapita diproksikan dengan PDRB perkapita. Model yang terbaik dalam estimasi model angka harapan hidup dan rata lama sekolah menggunakan fixed effect. Model terbaik dari persamaan pendapatan perkapita berdasarkan uji Chow dan uji Hausman menggunakan model random effect.

Tabel 2. Hasil Estimasi Pengaruh Belanja Pemerintah Terhadap Komponen IPM di Indonesia

\begin{tabular}{llll}
\hline Variabel & \multicolumn{1}{c}{$\begin{array}{c}\text { AHH } \\
(\mathbf{1})\end{array}$} & \multicolumn{1}{c}{$\begin{array}{c}\text { RLS } \\
\text { (2) }\end{array}$} & \multicolumn{1}{c}{$\begin{array}{c}\text { LnInc } \\
\text { (3) }\end{array}$} \\
\hline \hline C & $49.21601 * * *$ & $-5.574187 * * *$ & $25.49967 * * *$ \\
& $(0.852784)$ & $(0.554868)$ & $(0.173228)$ \\
LNTOTPE & $0.700781 * * *$ & $0.478891 * * *$ & $0.246503 * * *$ \\
& $(0.026143)$ & $(0.018649)$ & $(0.006085)$ \\
\hline Observations & 362 & 362 & 362 \\
R. square (adj) & 0.687815 & 0.664771 & 0.687815 \\
F-statistic & 7.963 .668 & 7.168 .748 & 7.963 .668 \\
Prob(F-statistic) & 0.000000 & 0.000000 & 0.000000 \\
\hline \hline
\end{tabular}

Sumber : Hasil perhitungan

Keterangan: Variabel LNTOTPE merupakan variabel kombinasi dalam bentuk logaritma yang terdiri dari belanja pemerintah fungsi ekonomi, kesehatan, pendidikan, infrastruktur.

Signifikan 1\%(***), 5\%(**), 10\%(*).

Model penelitian yang digunakan yaitu model Generalized Least Square (GLS) untuk melakukan koreksi uji asumsi klasik seperti autokorelasi dan heterokedastisitas (Gujarati, 2006). Pada Tabel 2 diatas, variabel pengeluaran pemerintah memengaruhi signifikan terhadap angka harapan hidup $(\mathrm{AHH})$, rata lama sekolah (RLS) dan pendapatan perkapita. Menurut Edeme, (2014) menjelaskan bahwa pengeluaran pemerintah akan membantu dalam pembentukan modal manusia yang lebih baik. Haque \& Khan, (2019) menunjukkan bahwa pengeluaran pemerintah untuk pendidikan, kesehatan, dan ekonomi berpengaruh signifikan positif terhadap setiap komponen indeks 
pembangunan manusia. Selain itu, pengeluaran pemerintah untuk infrastruktur berpengaruh signifikan terhadap indeks pendidikan dan indeks pendapatan namun tidak berpengaruh signifikan terhadap indeks kesehatan. Lebih lanjut, studi ini memberikan hasil yang berbeda dari belanja pemerintah di daerah tertinggal dan maju. Widodo, Waridin, \& Kodoatie, (2012) menunjukkan bahwa peningkatan belanja pemerintah di bidang pendidikan dan kesehatan tidak hanya diikuti oleh peningkatan IPM tetapi juga oleh penurunan persentase penduduk adalah penduduk miskin. Selain itu, hubungan antara pengeluaran pemerintah di bidang pendidikan dan kesehatan dengan pengentasan kemiskinan diperkuat oleh peran HDI. Akibatnya, pengeluaran pemerintah di bidang pendidikan dan kesehatan tidak dengan sendirinya berpengaruh langsung terhadap pengentasan kemiskinan. Haque \& Khan, (2019) menyatakan bahwa pengeluaran untuk pendidikan memberikan kontribusi terbesar terhadap HDI. Studi ini juga menemukan hubungan terbalik antara pengeluaran kesehatan dan pertumbuhan ekonomi di Arab Saudi. Temuan ini menghasilkan rekomendasi untuk merampingkan sektor kesehatan. Terakhir, studi tersebut memprediksikan bahwa indeks IPM akan menjadi 0,94 pada tahun 2030. R. K. Edeme et al., (2017), memberikan bukti bahwa distribusi pengeluaran publik akan meningkatkan tingkat pembangunan manusia. Perkembangan manusia yang lebih baik akan mengarah pada hidup sehat dan harapan hidup yang lebih besar. Pengeluaran pemerintah (public expenditure) untuk pembangunan manusia tercermin dari perubahan komposisi pengeluaran publik yang didasarkan dari perkembangan kualitas SDM setiap tahunnya.

\section{SIMPULAN}

Pengeluaran bidang ekonomi, kesehatan, pendidikan dan infrastruktur berpengaruh secara statistik terhadap indeks pembangunan manusia (IPM). Pengeluaran pemerintah sektor publik termasuk pengeluaran ekonomi, kesehatan, pendidikan dan infrastruktur memengaruhi signfikan terhadap indicator pembentuk IPM (AHH, RLS dan pendapatan perkapita). Kebijakan pemerintah dalam merencanakan anggaran berbasis kinerja akan menghasilkan pembangunan positif untuk sektor pendidikan, kesehatan, pendapatan perkapita dan IPM. Perencanaan anggaran belanja menjadi penentu keberhasilan pembangunan manusia.

Pengeluaran publik dialokasikan dalam penyediaan infrastruktur pendidikan dan kesehatan sesuai kebijakan pemerintah yang dicantumkan dalam perarturan pemerintah maupun undang-undang. Dana yang dibutuhkan untuk perlengkapan pendidikan dan kesehatan yang tidak sedikit maka anggaran belanja pendidikan dan kesehatan dapat diprioritaskan dibandingkan anggaran belanja lainnya.

Pengeluaran kesehatan yang lebih kecil dibandingkan pendidikan maupun ekonomi secara tidak langsung anggaran kesehatan yang dikeluarkan tidak memiliki pengaruh cukup besar terhadap IPM di Indonesia. Anggaran kesehatan yang relatif kecil memberikan dampak tidak langsung terhadap perkembangan IPM. Dengan demikian, peningkatan pengeluaran pemerintah perlu memperhatikan besaran penerimaan pendapatan pemerintah di setiap daerah. Pengeluaran pemerintah yang cukup besar dikarenakan daerah tersebut memiliki penerimaan yang cukup besar. Bagi daerah yang memiliki potensi penerimaan besar melaiui pajak atau transfer membuat perencanaan anggaran belanja untuk pembangunan manusia tidak mengalami kesulitan. Anggaran belanja pendidikan dan kesehatan yang direncanakan dengan baik diharapkan dapat mengurangi ketidakmerataan kualitas SDM antar daerah di Indonesia.

Pengeluaran pendidikan, kesehatan, ekonomi dan infrastruktur akan membantu pengembangan kapasitas pengetahuan dan teknologi bagi masyarakat untuk mendorong pembangunan berkelanjutan. Dengan demikian, pemerintah perlu meningkatkan belanja modal untuk keperluan kapasitas SDM, berdasarkan teori pertumbuhan endogen bahwa investasi modal manusia akan memberikan limpahan pengetahuan yang mengarah terhadap pertumbuhan ekonomi. Investasi modal manusia berbentuk penelitian dan pengembangan keterampilan menjadi 
proyek penanaman modal yang dikhususkan untuk masyarakat putus sekolah. Penegakan anti korupsi di sektor publik agar anggaran yang digunakan untuk peningkatan SDM dapat berjalan efektif dan efisien terutama pengembangan modal manusia. Perlunya penelitian lebih lanjut mengenai dampak pengeluaran pemerintah terhadap pembangunan manusia dalam ruang lingkup perdesaan termasuk desa tertinggal.

\section{DAFTAR PUSTAKA}

Arubayi, E. A., \& Ikoya, P. O. (2009). Variability in Regional Access to Higher Education in Nigeria: Implication for Equity and Even Development among the Niger Delta States. Journal of Social Sciences, 20(2), 143-148. https://doi.org/10.1080/09718923.2009.1 1892732

Astri, M., Nikensari, S. I., \& Kuncara W., H. (2013). Pengaruh Pengeluaran Pemerintah Daerah Pada Sektor Pendidikan Dan Kesehata Terhadap Indeks Pembangunan Manusia Di Indonesia. Jurnal Pendidikan Ekonomi Dan Bisnis (JPEB), l(1), 77. https://doi.org/10.21009/jpeb.001.1.5

Edeme, R. K. (2014). Analyzing the Effects of Sectoral Public Spending On Human Development in Nigeria: Evidence from Panel Data. IOSR Journal of Humanities and Social Science, 19(9), 01-13. https://doi.org/10.9790/0837-19960113

Edeme, R. K., \& Nkalu, C. N. (2019). Public Expenditure and Human Development in Nigeria in The Last Decade, Composition and Distributional Impacts. Economics and Business Letters, 8(2), $62-73$.

https://doi.org/10.17811/ebl.8.2.2019.6273

Edeme, R. K., Nkalu, N., \& Ifelunini, I. (2017). Distributional Impact of Public Expenditure on Human Development in Nigeria. International Journal of Social Economics, 44(12), 1683-1693. https://doi.org/10.1108/IJSE-05-20160152
Fadilah, A., Ananda, C. F., \& Kaluge, D. (2018). A Panel Approach: How Does Government Expenditure Influence Human Development Index? Jurnal Ekonomi Dan Studi Pembangunan, 10(2), 130-139.

Fransisco, Firdaus, M., \& Mulatsih, S. (2019). Strategi Alokasi Belanja Pemerintah Daerah Dalam Meningkatkan IPM di Provinsi Jambi. Jurnal Manajemen Pembangunan Daerah, 8(2), 1-13. https://doi.org/10.29244/jurnal_mpd.v8i 2.24816

Gujarati, D. N. (2006). Essentials of Econometrics. McGraw-Hill/Irwin.

Hao, E., \& Fan, J. (2001). Design and Implementation of the Vietnam Human Development Programmes-the Poor or the Shocked'. World Bank Policy Research Working Paper, (2436).

Haque, M. I., \& Khan, M. R. (2019). Role of oil production and government expenditure in improving human development index: Evidence from Saudi Arabia. International Journal of Energy Economics and Policy, 9(2). https://doi.org/10.32479/ijeep.7404

Jung, H.-S., \& Thorbecke, E. (2003). The Impact of Public Education Expenditure on Human Capital, Growth, and Poverty in Tanzania and Zambia: A General Equilibrium Approach. Journal of Policy Modeling, 25(8), 701-725.

Kusharjanto, H., \& Kim, D. (2011). Infrastructure and Human Development: The Case of Java, Indonesia. Journal of the Asia Pacific Economy, 16(1), 111124.

https://doi.org/10.1080/13547860.2011.5 39407

Mahumud, R. A., Hossain, G., Hossain, R., Islam, N., \& Rawal, L. (2013). Impact of Life Expectancy on Economics Growth and Health Care Expenditures in Bangladesh. Universal Journal of Public Health, 1(4). https://doi.org/10.13189/ujph.2013.0104 
05

Menteri Keuangan Republik Indonesia. Peraturan Menteri Keuangan Republik Indonesia Nomor 127/PMK.02/2015 Tentang Klasifikasi Anggaran (2015).

Mohanty, A. K., Nayak, N. C., \& Chatterjee, B. (2016). Does Infrastructure Affect Human Development? Evidences from Odisha, India. Journal of Infrastructure Development, $\quad 8(1), \quad 1-26$. https://doi.org/10.1177/09749306166400 86

Ocampo, J. A. (1998). Income Distribution, Poverty, and Social Expenditure in Latin America.

Pemerintah Republik Indonesia. UndangUndang Republik Indonesia Nomor 20 Tahun 2003 (2003).

Razmi, M. J., Abbasian, E., \& Mohammadi, S. (2012). Investigating the Effect of Government Health Expenditure on HDI in Iran. Journal of Knowledge Management, Economics and Information Technology, 2(5), 126-139.

Sahn, D. E., \& Younger, S. D. (1999). Dominance Testing of Social Sector Expenditures and Taxes in Africa. IMF Working Papers (Vol. 99). https://doi.org/10.5089/9781451875430. 001

Sanggelorang, S. M. M., Rumate, V. A., \& Siwu, F. D. J. (2015). Pengaruh Pengeluaran Pemerintah Di Sektor Pendidikan Dan Kesehatan Terhadap Indeks Pembangunan Manusia Di Sulawesi Utara. Http://Www.Sulutprov.Go.Id/MengenalSulut/Sejarah/, 15(02), 1-11.

Saraswati, E. (2013). Public Spending Education and Inequality: A Case Study in Indonesia. International Journal of Social Science and Humanity, 2(5), 427431.

https://doi.org/10.7763/ijssh.2012.v2.13 9
Sartiyah, ., Hartoyo, S., Syaukat, Y., \& Oktaviani, R. (2017). The Effect of Government Spending on Education to Human Capital in ACEH Province. Journal of Economic Development, Environment and People, 6(4), 18. https://doi.org/10.26458/jedep.v6i4.559

Sen, A. (2000). A Decade of Human Development. Journal of Human Development, $\quad 1(1), \quad 17-23$. https://doi.org/10.1080/14649880050008 746

Supadi. (2011). Disparitas kualitas sumber daya manusia di 35 kabupaten dan kota di propinsi jawa tengah. Eko-Regional, 6(2), 97-106. https://doi.org/doi.org/10.20884/1.erjpe. 2011.6.2.448

Todaro, M. P., \& Smith, S. C. (2012). Economic Development. AddisonWesley.

Widodo, A., Waridin, W., \& Kodoatie, J. M. (2012). Analisis Pengaruh Pengeluaran Pemerintah Di Sektor Pendidikan Dan Kesehatan Terhadap Pengentasan Kemiskinan Melalui Peningkatan Pembangunan Manusia Di Provinsi Jawa Tengah. Jurnal Dinamika Ekonomi Pembangunan, $1(1)$. https://doi.org/10.14710/jdep.1.1.25-42

Widodo, P., Irawan, L. A., Oktavianti, I. N., \& Anisa, L. (2020). Government Spending On Education, Health, And Minimum Wages As Predictors Of Human Development Index: Study Of Selected Provinces Of IndonesiA. International Journal of Advanced Economics, $1(2)$. https://doi.org/10.51594/ijae.v1i2.57

Wijayanto, A., Syafitri, W., \& Khusaini, M. (2015). The Analysis of Health and Educational Expenditure as Well as PDRB Per Capita's Influence on Human Development Index (Study of Cities/Regencies at East Java Province). International Journal of Social and Local Economic Governance, 1(2), 85- 
95.

https://doi.org/10.21776/ub.ijleg.2015.00 1.02.1

\section{DATA PENULIS}

Adhitya Wardhana adalah Dosen Departemen Ilmu Ekonomi Fakultas Ekonomi dan Bisnis Universitas Padjadjaran Bandung. Menyelesaikan Strata 3 di Universitas Padjadjaran, mempunyai ketertarikan penelitian bidang Ekonomi Pembangunan.

Bayu Kharisma adalah Dosen Departemen Ilmu Ekonomi Fakultas Ekonomi dan Bisnis Universitas Padjadjaran Bandung. Menyelesaikan Strata 3 di UGM Jogjakarta, mempunyai ketertarikan penelitian bidang Ekonomi Pembangunan.

Dita Selyna Sulandari adalah Asisten Dosen Departemen Ilmu Ekonomi Fakultas Ekonomi dan Bisnis Universitas Padjadjaran Bandung. Menyelesaikan Strata 1 di Universitas Padjadjaran, mempunyai ketertarikan penelitian bidang Ekonomi Pembangunan. 